\title{
Pneumomediastinum after Endobronchial Ultrasound-Guided Transbronchial Needle Aspiration: A Case Report
}

\author{
Endobronşial Ultrason Rehberliğinde Transbronşial İğne Aspirasyonu Sonrası \\ Gelişen Pnömomediasten: Olgu Sunumu
}

Ali Kadri Çırak, Sami Deniz, Dursun Alizoroğlu

\begin{abstract}
Pneumomediastinum is defined as an abnormal accumulation of air within the mediastinum. It occurs most often when increased alveolar pressure leads to alveolar rupture, and less frequently when there is perforation of the tracheobronchial tree. Pressure gradients then allow air to spread via the fascia to the surrounding soft tissues, mediastinum, and/or retroperitoneum. This is a report of a case of pneumomediastinum following endobronchial ultrasoundguided fine needle aspiration (EBUS/TBNA) of the mediastinal lymph nodes, widely regarded as a safe procedure.
\end{abstract}

Key words: EBUS/TBNA, complication, pneumomediastinum.

\section{Özet}

Pnömomediasten mediasten içine anormal şekilde havanın birikmesi olarak tanımlanmaktadır. Sıklıkla alveoler basıncın artışı sonucu alveol rüptürü olduğunda ve daha az olarak da trakeobronşial ağacın perforasyonu sonucunda meydana gelmektedir. Basınç farklığı nedeniyle hava, yumuşak dokuları saran fasya boyunca mediasten ve/veya retroperitonal bölgeye ulaşır. Genelde güvenli bir işlem olarak bilinen endobronşial ultrason eşliğinde yapılan mediastinal lenf bezi iğne aspirasyonu sonrası pnömomediasten gelişen olguyu sunuyoruz.

Anahtar Sözcükler: EBUS/TBNA, komplikasyon, pneumomediastinum.
Mediastinal lymph node sampling is a critical step in the staging of lung cancer and in the diagnosis of inflammatory conditions, such as sarcoidosis $(1,2)$. Over the past decade, endobronchial ultrasound-guided transbronchial needle aspiration (EBUS-TBNA) has emerged as a minimally invasive, highly accurate technique for sampling intrathoracic lymph nodes, with a sensitivity of $88 \%$ to $93 \%$ in distinguishing lymph node metastases from benign conditions (3) It uses an ultrasonic bronchofiberscope with a convex probe (CP-EBUS; XBF-
UC160F-OL8/BC-UC260F-OL8; Olympus Medical Systems, Tokyo, Japan) that allows for real-time needle aspiration of mediastinal and hilar lymph nodes guided by ultrasound images. EBUS-TBNA was given an EU CE marking in July 2004 and US Food and Drug Administration approval in March 2006 (4). Complications specifically related to EBUS-TBNA are pneumothorax and bleeding $(5,6)$. Complications can be avoided through proper knowledge of the mediastinal anatomy and with bronchoscopy experience (7).

Health Sciences University Izmir Dr. Suat Seren Chest Diseases and Surgery Training and Research Hospital, İzmir, Turkey 


\section{CASE}

A 68-year-old woman, with a 30-pack-year history of tobacco use, was admitted with a dry cough. Computed tomography (CT) and positron emission tomography scanning of the lungs revealed a left upper lobe nodule (1.3 cm long axis diameter; SUVmax 4.0) and bilateral paratracheal, subcarinal lymph nodes (short axis $<1 \mathrm{~cm}$; SUVmax similar to mediastinal vascular tissue) (Figures 1 . 3). Bronchoscopy was performed with endobronchial ultrasound-guided fine needle aspiration (EBUS-TBNA) of nodal stations $4 R$ and 7, using a 22-gauge needle. EBUS-TBNA is performed in the bronchoscopy unit of the hospital as an outpatient procedure using convex-probe bronchoscopes (Olympus 7.5 MHz, BF-UC160F and BFUC160F-OL8; Olympus Optical, Tokyo, Japan) with an EU C2000 processor (Olympus Optical, Tokyo, Japan). The scope was inserted through the oral route, in the supine position and under local anesthesia with lidocaine and conscious sedation with intravenous midazolam. Since severe coughing continued during the procedure, samples could only be taken once from lymph node stations $4 \mathrm{R}$ and 7.

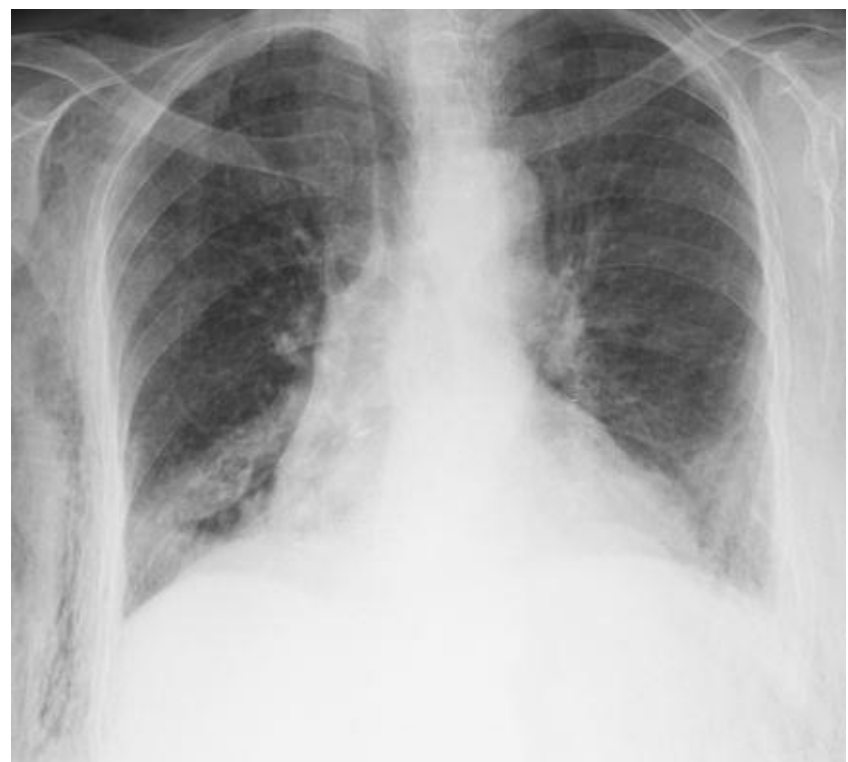

Figure 1: Pre-procedure chest $x$-ray

An hour after the procedure the patient complained of chest pain and swelling of the neck and chest wall. A physical examination detected tachycardia and crepitus that extended from the sternum to the neck. A postprocedure chest $\mathrm{X}$-ray and $\mathrm{CT}$ scan of the chest revealed extensive pneumomediastinum and subcutaneous emphysema (Figure 4 and 5). She was hemodynamically stable. Thoracic surgery was performed and a small incision was made to relieve the subcutaneous emphysema. After 48 hours of close monitoring, the crepitus and radiological findings markedly improved. The cytopathology of lymph node stations $4 R$ and 7 was benign. The patient declined to pursue advanced diagnostic procedures.

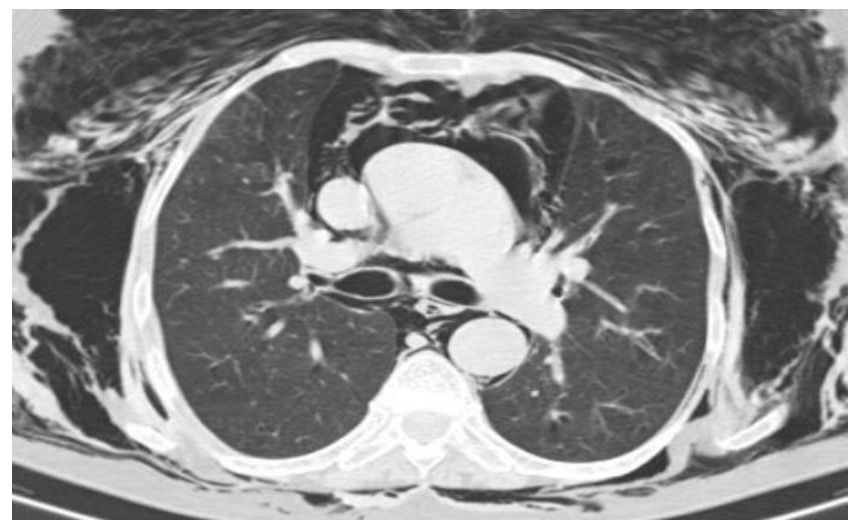

Figure 2: A pre-procedure CT sacan of the chest

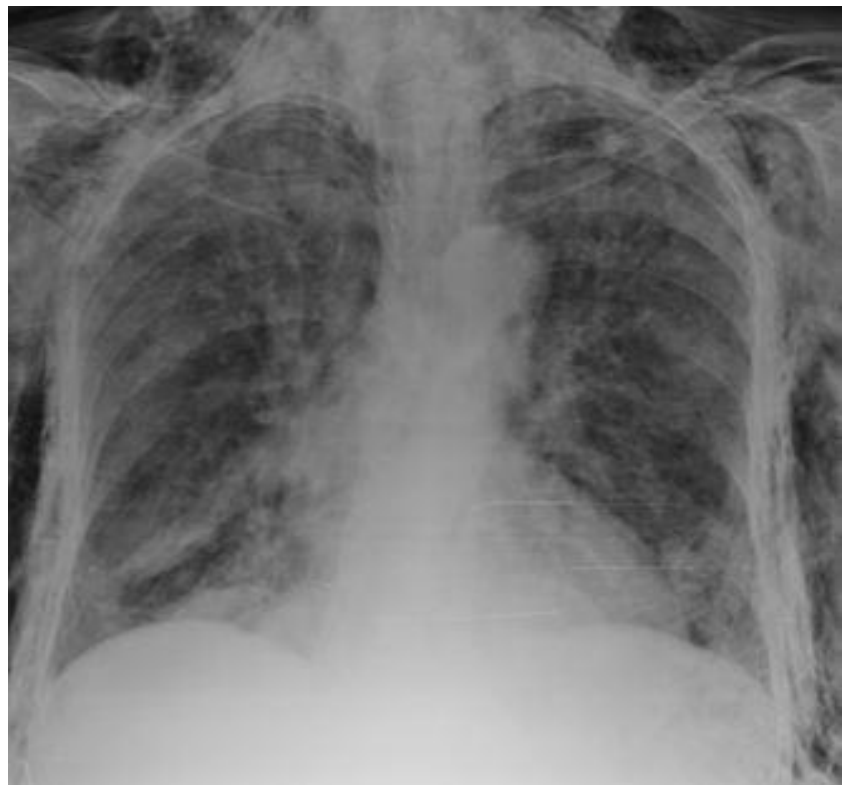

Figure 3: A post-procedure chest $x$-ray

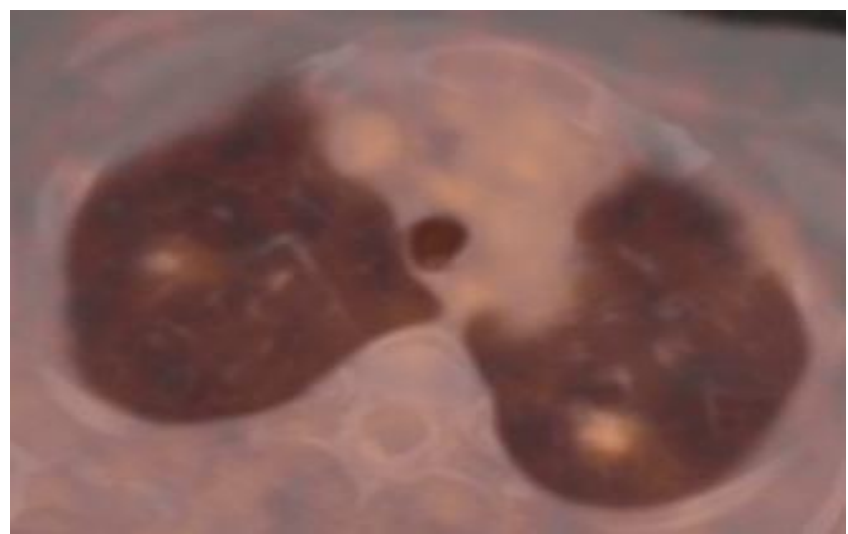

Figure 4: A pre-procedure PET-CT scan of the chest

\section{DISCUSSION}

Pneumomediastinum is defined as an abnormal accumulation of air within the mediastinum (8). It was first de- 
scribed by Hamman in 1939 (9). There are 3 reasons pneumomediastinum may occur: soft tissue infection, mucosal disruption, and spontaneous pneumomediastinum (10). While any one or combination of these mechanisms can lead to an abnormal accumulation of air in the mediastinum, most cases of intraprocedural iatrogenic pneumomediastinum are caused by the Macklin effect (The proposed mechanism is alveolar rupture with air dissecting along the peribronchovascular interstitial sheaths, interlobular septa, visceral pleura, and into the mediastinum) (11) or ventilation-induced barotrauma that causes mucosal disruption and spreading of air to nearby tissues via the fascial planes that connect them (12). Another potential cause of pneumomediastinum following bronchoscopy is blunt airway trauma from the bronchoscope. Additionally, forceful coughing can lead to tracheal microperforation, which can cause pneumomediastinum. Adequate sedation is an important part of EBUSTBNA, since it provides patient comfort and potentially increases the diagnostic yield. Two common types of sedation used in EBUS-TBNA: (1) Deep sedation (DS) or general anesthesia, and (2) moderate sedation (MS) or conscious sedation. DS using propofol has an acceptable safety profile in endoscopic procedures. MS is mostly preferred for procedures that require rapid recovery. A combination of fentanyl and midazolam is commonly used in endoscopic procedures for sedation. Local anesthesia of the airways is achieved by nebulizing $1 \%$ or $2 \%$ lidocaine and spraying lidocaine in the posterior pharynx (13).

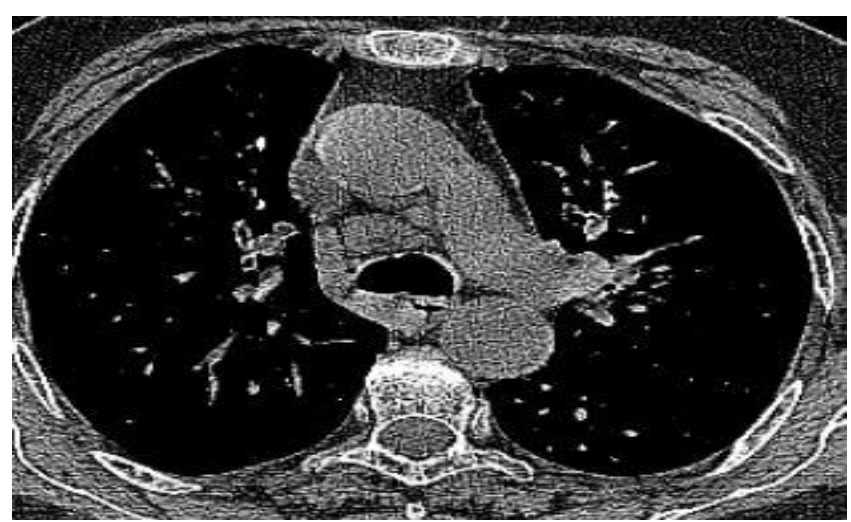

Figure 5: A post procedure CT scan of the chest

The cause of the pneumomediastinum in the present patient was likely a tracheal microperforation due to forceful coughing. Even though nearly all patients are administered adequate anesthesia (midazolam and propofol), because of some contraindications, this patient was just given midazolam. As a result, the patient's cough reflex continued during the operation.

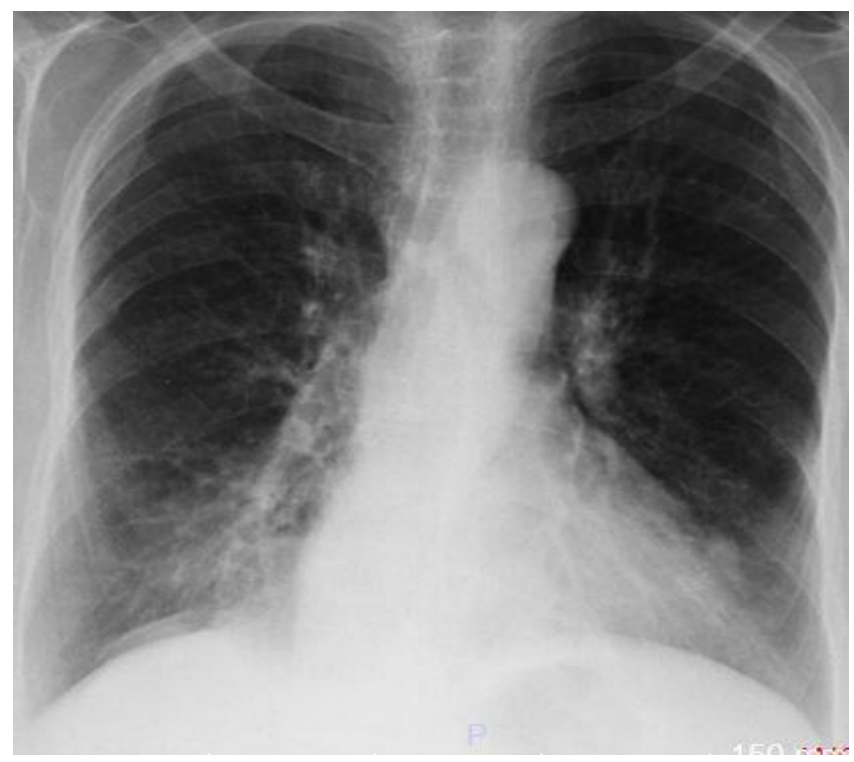

Figure 6: Two days after procedure chest $x$-ray

Often accompanied by chest pain, an acute onset of dyspnea, and swelling of the neck, chest wall, and face, pneumomediastinum can be diagnosed easily on chest $X$ ray films. Radiological features of pneumomediastinum include visualization of subcutaneous emphysema and free mediastinal air as hyperlucent lines enhancing the mediastinal viscera and outlining the lateral heart borders along with superior mediastinal widening. Other signs include a continuous diaphragm sign, a continuous left hemidiaphragm sign, a ring-around-the-artery sign (air surrounding the extrapericardial segment of the right main pulmonary artery and appearing as a lucent ring around the right pulmonary artery), a thymic/spinnaker sail sign (outlining of the thymus due to large pneumomediastinum elevating the thymic lobes), a $V$ sign (confluence of innominate veins outlined in a frontal view), a Naclerio's $V$ sign (air outlining the lateral border of the descending aorta and extending laterally between the parietal pleura and the medial left hemidiaphragm), pneumopericardium, air in the pulmonary ligament, a tubular artery sign, a double bronchial wall sign, and an extrapleural sign. A lateral chest $\mathrm{X}$-ray is also helpful in detecting increased retrosternal air, and increases the rate of detection of pneumomediastinum. Vertical translucent air streaks around the aorta and pulmonary artery are also diagnostic of pneumomediastinum $(8,14)$. Our patient had trouble with chest pain and swelling of the neck and chest wall. The radiological features of our patient included the visualization of subcutaneous emphy- 
sema, free mediastinal air as hyperlucent lines highlighting the mediastinal viscera and outlining the lateral heart borders, along with superior mediastinal widening.

Over the last 2 decades, EBUS has emerged as a highly effective and minimally invasive technique for sampling peribronchial, mediastinal, and lung masses for pathological examination. Although initial studies of EBUSTBNA focused on evaluating diagnostic performance, an impressively low complication rate has also been reported (5) (Table 1).

Table 1: Complications following endobronchial ultrasound-guided transbronchial needle aspiration

\begin{tabular}{|l|l|}
\hline \multicolumn{1}{|c|}{ Outcome } & \multicolumn{1}{|c|}{$\begin{array}{c}\text { Complication rate, \% (95\% } \\
\text { confidence interval) }\end{array}$} \\
\hline Any complication within 24 hours & $1.44(0.87-2.24)$ \\
\hline Bleeding requiring intervention & $0.2(0.05-0.7)$ \\
\hline Pneumothorax & $0.53(0.21-1.1)$ \\
\hline Clinically significant airway injury & $0.1(0.002-0.4)$ \\
\hline Sustained hypoxia & $0.3(0.08-0.8)$ \\
\hline Hypotension & $0.1(0.002-0.4)$ \\
\hline Respiratory failure within 24 hours & $0.23(0.05-0.7)$ \\
\hline
\end{tabular}

EBUS-TBNA was performed 11,753 times (3.76/case) at 6115 lymph node stations and lesions (1.92/station or lesion) by Çağlayan at al. (15) Five instances of a serious complication were recorded (0.16\%): fever lasting $>24$ hours, infection of bronchogenic cyst, mediastinal abscess, pericarditis, and pneumomediastinitis with empyema.

In another study, EBUS-TBNA was performed using a convex probe in 7345 cases. Complications (except pneumomediastinum) were observed in 90 cases (1.23\%; 95\% confidence interval: $0.97 \%-1.48 \%$ ) in 32 facilities (15.2\%). Lymph node station 7 was the most frequently sampled, in 34 patients (43.0\%), followed by $4 R$, in 24 patients $(30.4 \%)$. The number of samples taken in any lymph node was 1 in 24 cases (57.1\%), 2 in 14 cases (33.3\%), 3 in 1 case (2.4\%), and 4 in 3 cases (7.1\%). A 22 -gauge needle was used in 30 cases (85.7\%) and a 21 -gauge needle was used in 5 cases (14.3\%) with hemorrhage. There was no information about sampling in 7 cases (16). In our patient, we took samples from lymph node stations $4 \mathrm{R}$ and 7 once while using a 22-gauge needle.

Procedural training has long been an important component in the specialty of pulmonary medicine. The American Thoracic Society/European Respiratory Society and CHEST guidelines based on the number of procedures have not been proven adequate to determine competence (40 procedures for EBUS-TBNA). Ideal outcomes might include diagnostic yield, complication rates, and patient tolerance. Some training programs have been moving toward incorporating simulation training and web-based virtual bronchoscopy training. In summary, no validated methods of determining competency exist at this time (17). Before this patient, we had a total of 250 bronchoscopy patients.

The management of pneumomediastinum depends on the clinical severity and the underlying etiology. Spontaneous pneumomediastinum has a benign course, resolving on its own. The management of this condition is usually supportive, with reassurance, observation, treatment of underlying condition, and oxygen therapy. In rare cases, surgery may be required to correct pneumomediastinum when caused by severe tracheobronchial disruption. However, occasional deaths from splinting of great vessels and the trachea by mediastinal emphysema have also been reported, demanding careful vigilance of this condition (10). The lack of pneumothorax in our patient, which is often a secondary complication of pneumomediastinum, combined with the lack of any identifiable lesion and hemodynamic stability, allowed for conservative management.

In conclusion, we reported a case of iatrogenic pneumomediastinum during EBUS-TBNA. Despite being rare, this is a complication that can occur and must be recognized promptly to avoid delay in treatment if clinically indicated. In addition to a highlighting a rare complication of EBUSTBNA, we also wanted to emphasize the importance of anesthesia.

\section{CONFLICTS OF INTEREST}

None declared.

\section{AUTHOR CONTRIBUTIONS}

Concept - A.K.Ç., S.D., D.A.; Planning and Design A.K.Ç., S.D., D.A.; Supervision - A.K.Ç., S.D., D.A.; Funding - A.K.Ç., S.D.; Materials - S.D.; Data Collection and/or Processing - A.K.Ç., S.D., D.A.; Analysis and/or Interpretation - S.D.; Literature Review - D.A.; Writing A.K.Ç.; Critical Review - S.D., D.A.

\section{YAZAR KATKILARI}

Fikir - A.K.Ç., S.D., D.A.; Tasarım ve Dizayn - A.K.Ç., S.D., D.A.; Denetleme - A.K.Ç., S.D., D.A.; Kaynaklar A.K.Ç., S.D.; Malzemeler - S.D.; Veri Toplama ve/veya İşleme - A.K.Ç., S.D., D.A.; Analiz ve/veya Yorum - S.D.; 
Literatür Taraması - D.A.; Yazıyı Yazan - A.K.Ç.; Eleştirel Inceleme - S.D., D.A.

\section{REFERENCES}

1. Detterbeck FC, Jantz MA, Wallace M, Vansteenkiste J, Silvestri GA. American College of Chest Physicians. Invasive mediastinal staging of lung cancer: ACCP evidencebased clinical practice guidelines (2nd edition). Chest 2007; 132 (suppl 3): 202S-20S.

2. Wong M, Yasufuku K, Nakajima T, Herth FJ, Sekine Y, Shibuya K, et al. Endobronchial ultrasound: new insight for the diagnosis of sarcoidosis. Eur Respir J 2007; 29:1 182-6. [CrossRef]

3. Adams K, Shah PL, Edmonds L, Lim E. Test performance of endobronchial ultrasound and transbronchial needle aspiration biopsy for mediastinal staging in patients with lung cancer: systematic review and meta-analysis. Thorax 2009; 64:757-2. [CrossRef]

4. von Bartheld MB, van Breda A, Annema JT Complication rate of endosonography (endobronchial and endoscopic ultrasound): a systematic review. Respiration 2014;87:19. [CrossRef]

5. Eapen GA, Shah AM, Lei X, Jimenez CA, Morice RC, Yarmus $L$, et al. Complications, consequences, and practice patterns of endobronchial ultrasound guided transbronchial needle aspiration: results of the AQuIRE registry. Chest 2013; 143:1044-53. [CrossRef]

6. Yasufuku K, Chiyo M, Sekine Y, Chhajed PN, Shibuya K, lizasa $T$, et al. Real-time endobronchial ultrasoundguided transbronchial needle aspiration of mediastinal and hilar lymph nodes. Chest 2004; 126:122-8. [CrossRef]

7. Bolliger CT, Mathur PN, Beamis JF, Becker HD, Cavaliere $\mathrm{S}$, Colt $\mathrm{H}$, et al. ERS/ATS statement on interventional pulmonology: European Respiratory Society/ American Thoracic Society. Eur Respir J 2002; 19:356-73.
8. Bejvan SM, Godwin JD. Pneumomediastinum: old signs and new signs. AJR Am J Roentgenol 1996; 166:1041-8. [CrossRef]

9. Hamman L. Spontaneous mediastinal emphysema. Bull Johns Hopkins Hosp 1939; 64;1-21

10. Maunder RJ, Pierson DJ, Hudson LD. Subcutaneous and mediastinal emphysema: pathophysiology, diagnosis, and management. Arch Intern Med 1984; 144:1447-53. [CrossRef]

11. Macklin CC. Transport of air along sheaths of pulmonic blood vessels from alveoli to mediastinum. Arch Intern Med 1939; 64:913-26. [CrossRef]

12. Kumar A, Pontoppidan H, Falke KJ, Wilson RS, Laver MB. Pulmonary barotrauma during mechanical ventilation. Crit Care Med 1973; 1:181-6. [CrossRef]

13. Aswanetmanee $P$, Limsuwat $C$, Kabach $M$, Alraiyes $A H$, Kheir $F$. The role of sedation in endobronchial ultrasound-guided transbronchial needle aspiration: systematic review. Endosc Ultrasound 2016; 5:300-6.

14. Beyers JA, Melonas CF. The visible wall of a main bronchus: a new radiological sign of pneumomediastinum. $\mathrm{Br}$ J Radiol 1987; 60:877-9. [CrossRef]

15. Çağlayan B, Yılmaz A, Bilaçeroğlu S, Cömert SŞ, Demirci NY, Salepçi B. Complications of convex-probe endobronchial ultrasound-guided transbronchial needle aspiration: a multi-center retrospective study. Respir Care 2016; 61:243-8. [CrossRef]

16. Asano F, Aoe M, Ohsaki Y, Okada Y, Sasada S, Sato S, et al. Complications associated with endobronchial ultrasound-guided transbronchial needle aspiration: a nationwide survey by the Japan Society for Respiratory Endoscopy. Respir Res 2013, 14:50-8. [CrossRef]

17. Ernst A, Wahidi MM, Read CA, Buckley JD, AddrizzoHarris DJ, Shah PL, et al. Adult bronchoscopy training current state and suggestions for the future: CHEST Expert Panel Report. Chest 2015; 148:321-32. [CrossRef] 